\title{
Vegetation history and landscape development of the Friedländer Große Wiese region (Vorpommern, NE Germany) inferred from four pollen diagrams of Franz Fukarek
}

\author{
PiM De KLERK ${ }^{*)}$
}

Keywords: Friedländer Große Wiese/Galenbecker See, Holocene, Mecklenburg-Vorpommern, NE Germany, pollen analysis, Weichselian Lateglacial

\begin{abstract}
Previous unpublished pollen data of four profiles from the Friedländer Große Wiese region (Ueckermünder Heide, NE Germany) analysed by F. Fukarek cover - in combination with each other - the complete Holocene and almost the complete Weichselian Lateglacial. These data show that phases of development of a former proglacial lake known as the "Haffstausee" - which previously were dated to have lasted up to the end of the Lateglacial - are much older. With respect to a Lateglacial vegetational and climatic gradient in NE Germany, the study area mainly shows the patterns of S Mecklenburg, $\mathrm{N}$ Brandenburg, and the Berlin area, but temporarily belonged to a transitional area between $\mathrm{N}$ Vorpommern and the southern regions. Start of terrestrialisation in the basin of the Galenbecker See is unknown. A rise of the lake level and the inundation of the surrounding mire are now dated in the Late Medieval. A compilation of register maps shows a detailed picture of the landscape around A.D. 1700.
\end{abstract}

[Vegetationsgeschichte und Landschafts-entwicklung der „Friedländer Großen Wiese“ und ihrer Umgebung (Vorpommern, NO Deutschland) interpretiert aus vier Pollendiagrammen von Franz Fukarek]

*Anschrift des Verfassers: PIM DE KLERK, Institute of Botany and Landscape Ecology Ernst-MoritzArndt-University, Grimmer Straße 88, D-17487 Greifswald, Germany E-mail:pimdeklerk@web.de
Zusammenfassung: Bisher unveröffentlichte Pollendaten von vier Profilen aus der Umgebung der Friedländer Großen Wiese (Ueckermünder Heide, NO-Deutschland), analysiert von Franz Fukarek, umfassen - in Kombination miteinander - das gesamte Holozän und fast das gesamte Weichselspätglazial. Diese Daten zeigen, dass Entwicklungsphasen eines Eisstausees, bekannt als „Haffstausee“, die bisher bis zum Ende des Spätglazials datiert wurden, viel älter sind. Im Bezug auf einen spätglazialen Vegetationsund Klimagradienten in Nordostdeutschland zeigt das Untersuchungsgebiet hauptsächlich die Muster S-Mecklenburgs, N-Brandenburgs, und Berlins, aber zeitweise gehörte es zu einer Übergangszone zwischen N-Vorpommern und den südlichen Gebieten. Der Beginn der Verlandung im Becken des Galenbecker Sees ist unbekannt. Ein Seespiegelanstieg mit anschließender Überflutung der umgebenden Moore kann auf das späte Mittelalter datiert werden. Eine Zusammenstellung von Matrikelkarten zeigt ein detailliertes Bild der Landschaft um A.D. 1700.

\section{Introduction}

Franz Fukarek worked for many years as a plant geographer and palynologist at the Botanical Institute of the Greifswald University. His 'opus major' on plant distribution and its development of the Darß peninsula (FUKAREK 1961) found international appraisal (cf. IVERSEN 1962). In the mid-1960-ies he started palynological investigations in the Ueckermünder Heide in close co-operation with Horst Bramer who elaborately studied this area geomorpho- 

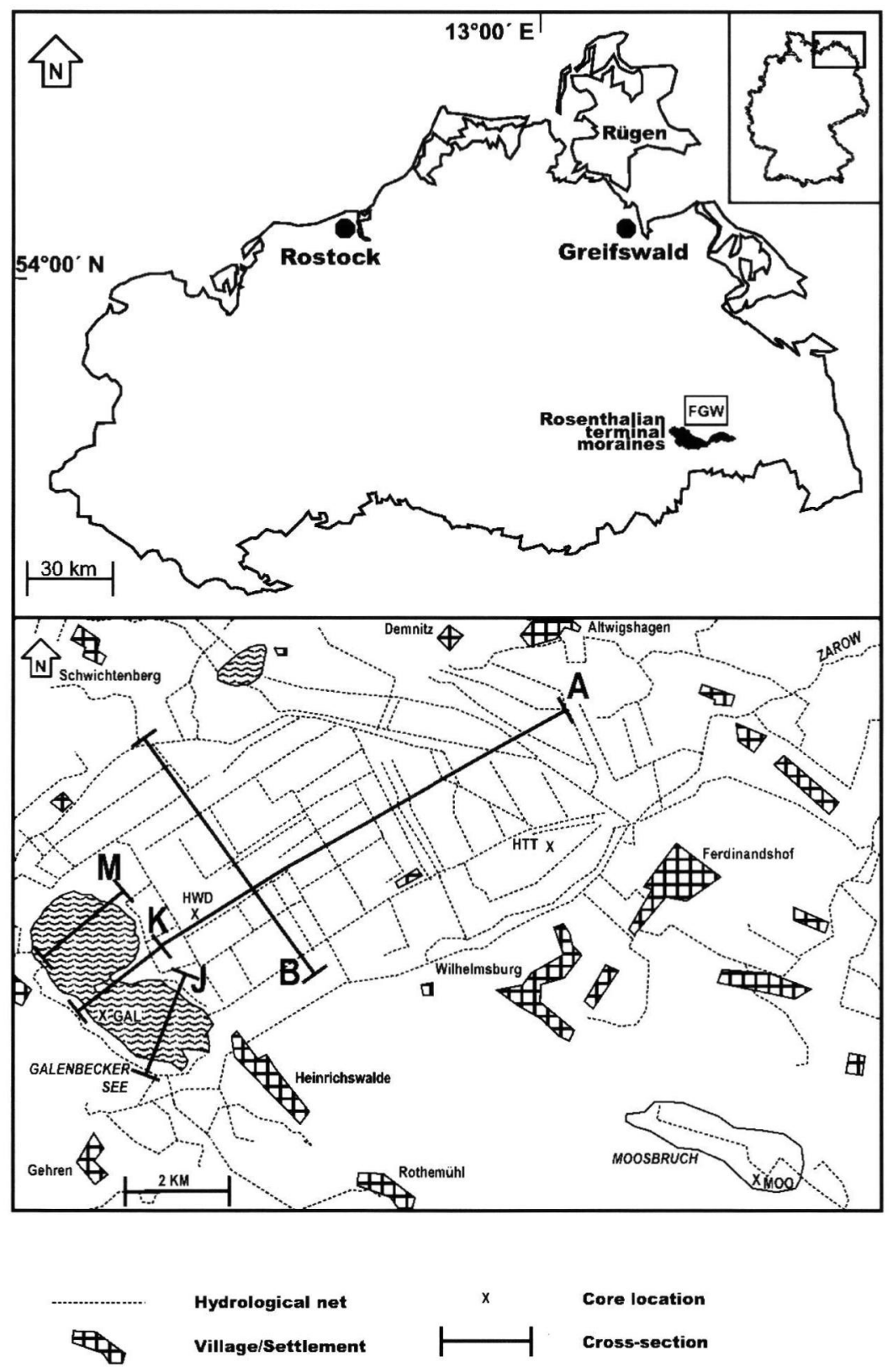

Fig. 1: Location of the Friedländer Große Wiese (FGW) and the Moosbruch in southeastern MecklenburgVorpommern (NE Germany). Indicated are the positions of cross-sections A and B (Fig. 2) and cross-sections J, K and M (Fig. 3), and the locations of the palynologically analysed cores "Galenbecker See-Rinne“ (GAL), „Heinrichswalder Damm“ (HWD), „Hüttendamm“ (HTT) and „Moosbruch“ (MOO).

Abb. 1: Lage der Friedländer Großen Wiese (FGW) und des Moosbruchs im Südosten von MecklenburgVorpommern (NO Deutschland). Angegeben sind die Lage der Querschnitte A und B (Abb. 2), der Querschnitte J, K und M (Abb. 3) und die Lage der palynologisch untersuchten Kerne „Galenbecker SeeRinne“ (GAL), „Heinrichswalder Damm“ (HWD), „Hüttendamm“ (HTT) and „Moosbruch“ (MOO). 
logically (BRAMER 1963, 1964, 1972, 1975, 1979). After surveying analyses of several cores dispersed over southern Mecklenburg-Vorpommern, five sites were selected for palynological studies, of which four were located around the "Friedländer Große Wiese" peatland (including a large lake, the "Galenbecker See"; cf. Fig. 1). Since the project did not fit in the research priorities of the Botanical Institute, it was ordered in 1966 by the "Prorektorat für Forschung" that it had to be carried out with reduced priority and personal capacity. The results were presented only in an unpublished report (FUKAREK 1968) and partly summarised in an unpublished Habilitation-thesis (BRAMER 1964). Only one very coarse pollen diagram of the surveying analyses from southern Mecklenburg was ever published (FuKAREK 1972).

Unfortunately, the report of FUKAREK (1968) contains some mistakes concerning the reconstruction of vegetation phases, probably because comparative pollen diagrams from NE Germany covering the Lateglacial and Early Holocene were still rare in the mid 1960-ies. These mistakes led to an erroneous reconstructed landscape development of the Ueckermünder Heide area in the studies of BrAmER (1964, 1972, 1975, 1979).

The Friedländer Große Wiese has always been an important area for research into genesis, ecology, conservation, and restoration of peatlands (e.g. Kuoss, 1966a, 1966b, 1970; SucCOW \& JeschKe 1990; Schmidt \& Scholz 1993; Scholz et al. 1995; Dietrich et al. 1996; Succow 2001; KoppISch et al. 2001; Roth et al. 2001). The area is furthermore important for the investigation of a possible Lateglacial climate gradient because of its location between the palynologically relatively wellknown areas of northern Vorpommern and southern Mecklenburg/N Brandenburg/Berlin area (cf. De KLERK submitted).

Pollen diagrams from the Ueckermünder Heide area are, unfortunately, still rare (e.g. KaISER et al. 2001, 2003; Jahns \& Herking 2002) and cover only part of the Weichselian Lateglacial and large part of the Holocene. Though the Fukarek-diagrams contain only limited amounts of pollen types and thus hardly correspond to the modern standard, they show (in combination with each other) an almost complete pollen sequence of these periods with relative high sample resolution. It is, therefore, important to make these diagrams available to the scientific community.

Additionally, some maps and descriptive texts of the so-called "Schwedische Matrikelkarte" - a register map from Vorpommern from ca. A.D. 1700 (cf. Wartenberg 1994; Asmus 1996) -were studied in order to get information on the vegetation and land-use surrounding the study area at the end of the $17^{\text {th }}$ Century.

\section{Description of the study area and location of the analysed cores}

The Ueckermünder Heide consists of deposits of a large former proglacial lake known as the "Haffstausee"; in its southwestern part, the Friedländer Große Wiese peatland (Fig. 1) fills an approximately $8 \times 12 \mathrm{~km}$ long depression in a former glacial valley (BRAMER 1963, 1964, 1972, 1975, 1979; Sснмidt \& Scholz 1993; SCHulz 1998; ReINCKe \& LÖSER 2000). The Rosenthalian terminal moraines are positioned immediately south of the peatland and mark a regionally restricted glacial advance after the melting of the Pomeranian inland ice (cf. Schulz 1965, 1998; Bramer 1979; Reincke \& LÖSER 2000).

The basal till in the glacial valley is covered with 6-11 $\mathrm{m}$ thick sand layers, which are interpreted to be englacial debris (Bramer 1964, 1979) or deposits of the proglacial lake (Schulz 1998). Two large basins - separated by a low sand ridge - occur in the area around the Galenbecker See and ca $1 \mathrm{~km}$ further to the northeast (Figs. 2,3). 


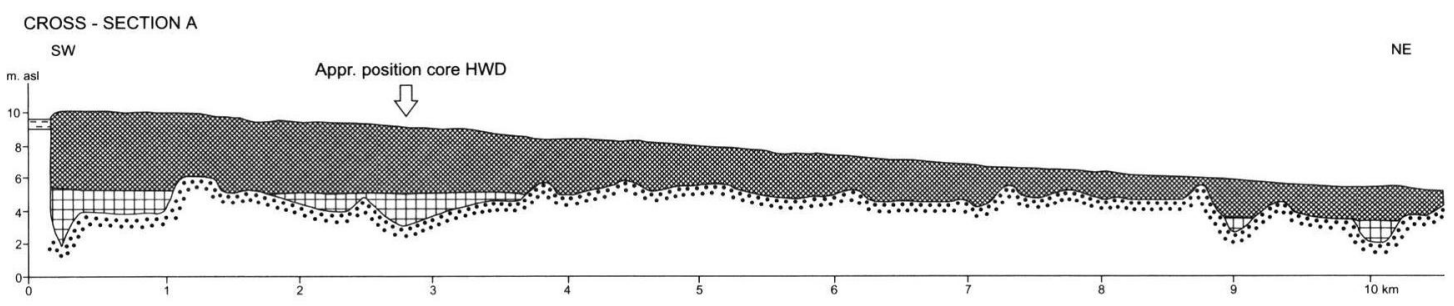

CROSS - SECTION K

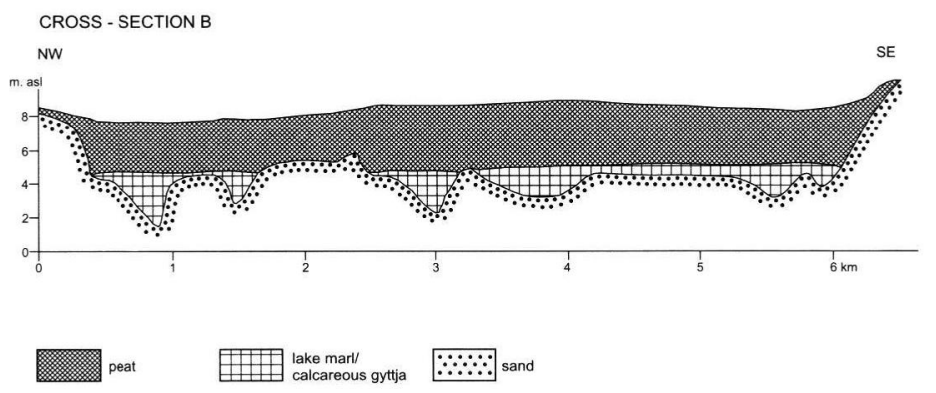

Fig. 2: Cross-sections A and B through the Friedländer Große Wiese, modified after Bramer (1979; cf. BRAMER 1964), predominantly based on archive material which did not differentiate between lake marl and calcareous gyttja (cf. Bramer 1964). The basin shown in cross-section A, around $\mathrm{km} 2$ and 3, contains core HWD. Due to peat oxidation after the 1960-ies (cf. Succow 2001), the indicated height asl. probably does not correspond to the present-day elevation.

Abb. 2: Querschnitte A und B durch die Friedländer Große Wiese, verändert nach Bramer (1979; vgl. BrAmEr 1964), hauptsächlich basierend auf Archivmaterial, in dem keine Differenzierung zwischen Seekreide und Kalkmudde vorgenommen wurde (vgl. Bramer 1964). Aus dem Becken in Querschnitt A wurde in der Nähe von Kilometer 2 und 3 der Kern HWD entnommen. Wegen der Torfmineralisation seit den 1960er Jahren (vgl. Succow 2001) entspricht die Torfoberfläche vermutlich nicht der heutigen Situation.

These, and many numerous smaller deep basins mentioned by Bramer $(1963,1964,1979)$ are primarily filled with lake marl and calcareous gyttja.

After the onset of peat formation a large percolation mire developed under influence of a continuous flow of seepage water from the Rosenthalian terminal moraines (Succow 2001; Succow \& Jeschke 1990; Schmidt \& Scholz 1993; Reincke \& Löser 2000). The peat is mainly Cyperaceae and Cyperaceae/ Phragmites peat, incidentally also wood peat (Bramer 1963, 1964, 1979). Though several sources indicate an initiation of drainage in the $18^{\text {th }}$ Century (Succow \& Jeschke 1990; Schmidt \& Scholz 1993; Succow 2001), in reality it had started earlier (cf. section 4.4). Deep drainage of the area since the 1960-ies (cf. Heller \& Schimanski 1966) and subsequent peat oxidation caused destruction of the upper 1.5-2 $\mathrm{m}$ of peat (Succow 2001).

The Galenbecker See is a large, shallow lake (Bramer 1963, 1964; cf. Fig. 3). The sandy subsoil in the eastern part of the lake basin is rather flat, whereas in the western part a deep channel-like basin exists (cf. Fig. 3). According to Bramer (1964) the mineral base of the channel lies at maximally $1 \mathrm{~m}$ below sea level, i.e. $2 \mathrm{~m}$ 

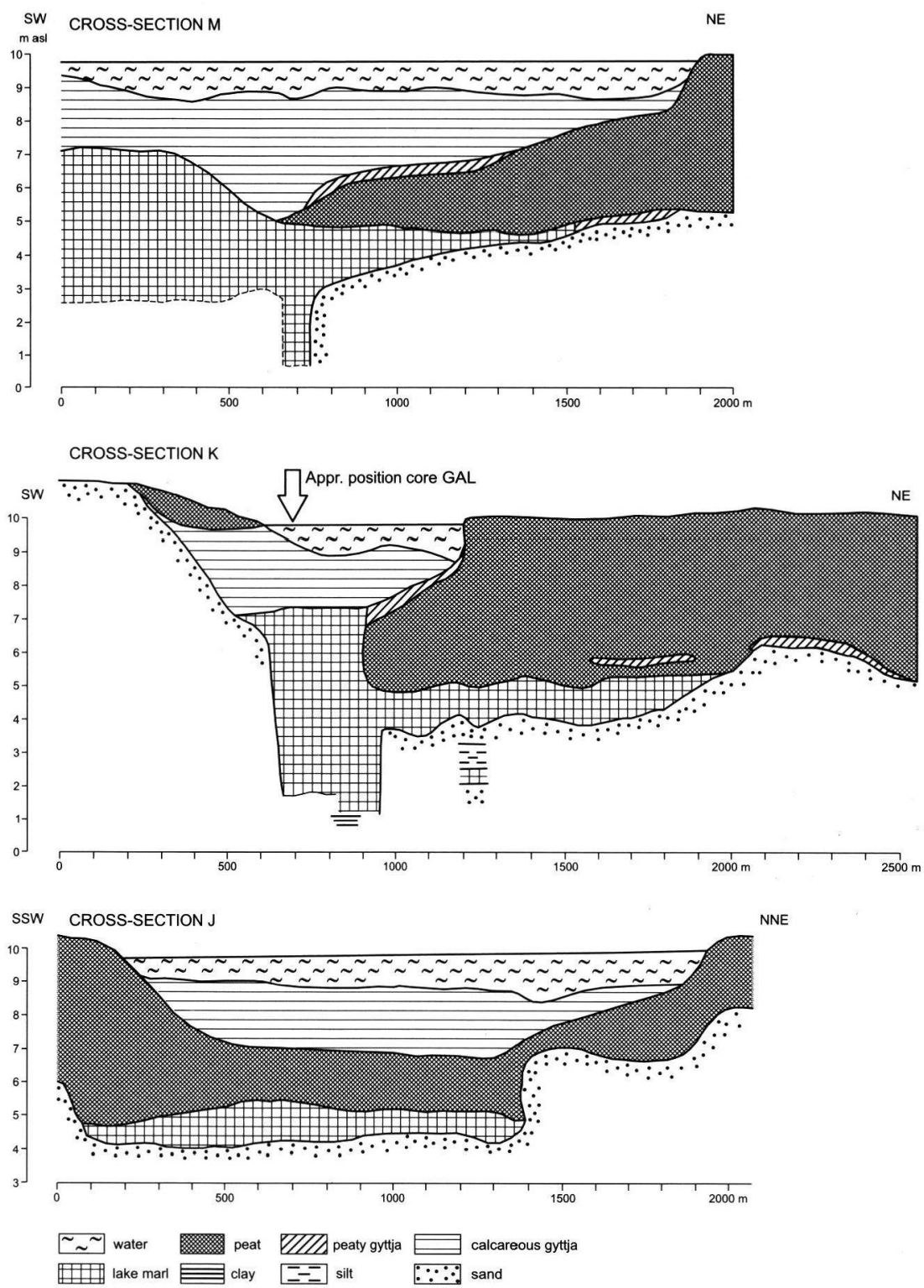

Fig. 3: Cross-sections $\mathrm{M}, \mathrm{K}$ and $\mathrm{J}$ through the Galenbecker See, drawn after original core descriptions and sediment columns of Bramer (1964). Sediment columns of cross-section $\mathrm{K}$ were also published in Bramer (1963). Close to $\mathrm{m} 700$ in cross-section K, core GAL must have been taken. Due to peat oxidation after the 1960-ies (cf. Succow 2001), does probably not correspond to the present-day elevation.

Abb. 3: Querschnitte M, K und J durch den Galenbecker See, gezeichnet nach Kernbeschreibungen, sowie Sedimentsäule von Bramer (1964). Sedimentsäulen von Querschnitt K wurden auch von Bramer (1963) veröffentlicht. Kern GAL wurde in der Nähe von Querschnitt K, Meter 700, entnommen. Wegen der Torfmineralisation seit den 1960er Jahren (vgl. Succow 2001) entspricht die Torfoberfläche vermutlich nicht der heutigen Situation. 
deeper than the deepest point indicated in the cross sections of Fig. 3; BRAMER (1963), however, mentions a coring up to $11 \mathrm{~m}$ below lake level (i.e. $1 \mathrm{~m}$ below sea level) without reaching the underlying sand, so the maximum depth of the channel-like basin remains unknown.

The basal lake sediments consist of lake marl, the top lake sediments are calcareous gyttja. One 'deep geological core' (cf. BRAMER 1964) in cross-section $\mathrm{K}$ around $1250 \mathrm{~m}$ (Fig. 3) shows that below the 'basal' sand other limnic sediments occur. BrAMER (1964) mentions that this phenomenon occurs incidentally also at other spots in the study area.

Thick peat layers occur along the lake shores and embedded between lake sediments (Fig. 3). This shows that in former times with lower water levels large parts of the original lake had been terrestrialised and that only a small lake, confined to the area of the deep channel, grew in height concomitant to the peat of the adjacent mire; after a rise in water level which was too rapid to be balanced by peat growth, the peat drowned and the lake enlarged its size (cf. Bramer 1963; Succow 2001; Succow \& JeSCHKE 1990). If the original basin shape and the present position of the lake are compared (Fig. 3 ), it shows that the lake moved in northeastern direction. Bramer (1963), comparing his observations with older maps, noted that the lake in recent time still had changed its shape, though Succow \& JesChKe (1990) assumed that the lake has not substantially changed during the last 2000 years.

Located between the Friedländer Große Wiese and the Rosenthalian terminal moraines are a series of coastal terraces from the former proglacial lake. This area includes many peat-filled basins of which the Moosbruch is the most prominent: it is surrounded by dunes that partly stretch-out into the basin, organic sediments reach over $6 \mathrm{~m}$ thickness and peat thickness seldom exceeds $2 \mathrm{~m}$ (cf. Bramer 1964, 1979). Core „Heinrichswalder Damm“ (HWD),
(Meßtischblatt: 2348 Galenbeck, R: 5417 300, H: 5946 200) (according to FuKareK (1968); coordinates presented by BRAMER (1964) indicate a slightly different position), $8.9 \mathrm{~m}$ asl. at the time of coring, originates from the fossil lake basin approximately $1 \mathrm{~km} \mathrm{NE}$ of the Galenbecker See (cf. Fig. 2). The core consists of ca $4 \mathrm{~m}$ Cyperaceae/wood peat, covering (sandy) lake marl up to $775 \mathrm{~cm}$ depth. Below a layer of unknown composition, at $810 \mathrm{~cm}$ depth again some lake marl was found that might represent a coring disturbance (cf. discussion below). The core „Hüttendamm“ (HTT), (Meßtischblatt: 2349 Ferdinandshof, R: 5423 390, H: 5948380 ), $6.3 \mathrm{~m}$ asl. at the time of coring, was recovered about $8 \mathrm{~km}$ further to the northeast from another basin in the subsoil. The core contained $235 \mathrm{~cm}$ Cyperaceae/wood peat over alternating layers of (peaty and silty) calcareous gyttja and lake marl to a total depth of 720 $\mathrm{cm}$.

The core „Moosbruch“ (MOO), (Meßtischblatt: 2349 Ferdinandshof, R: 5428 990, H: 59 $42390), 12 \mathrm{~m}$ asl. at the time of coring, stems from the peatland of the same name. It consists of $50 \mathrm{~cm}$ peat covering (sandy) lake marl up to $600 \mathrm{~cm}$ depth.

The core "Galenbecker See (Rinne)" (GAL), (Meßtischblatt 2348 Galenbeck, R: 5315 700, $\mathrm{H}$ : 5943 800), water level $9.7 \mathrm{~m}$ asl. at the time of coring, top of the sediments $80 \mathrm{~cm}$ below water surface, was derived from the channel-like depression in the Galenbecker See close to the $700 \mathrm{~m}$ mark in cross-section K (Fig. 3). It consists of $6 \mathrm{~m}$ calcareous gyttja and lake marl. An additional section of lake marl between 7.8 and $8 \mathrm{~m}$ depth and a single sample from $9 \mathrm{~m}$ depth were derived from the near surroundings.

\section{Methods}

Unfortunately, the unpublished report (FUKAREK 1968) does not provide information 
about the original research methods. It can be expected, however, that these are largely identical with the methods used in the Darß-study (FuKareK 1961). Corings were probably carried out with a "Hiller sampler". With respect to sample preparation, the Darß-study mentions the "common $\mathrm{KOH}$-method" and incidental use of the „Acetolysis method after Erdtman“ without further elaboration or references. Samples in the Darß-study were counted with a light microscope with an enlargement of 300 $\mathrm{x}$ up to exactly 200 pollen grains attributed to trees (excluding Corylus pollen), incidentally up to exactly 400 or 100 grains.
The original pollen diagrams (hand-drawn on mm-paper) were used to recalculate the data. Pollen type names as used by FuKarex (1968) were maintained in order to avoid an erroneous over-interpretation (e.g. is "Plant.“ or "Plantago" identical with Plantago lanceolata, or with Plantaginaceae undiff., or: does „Ericac." only include pollen types attributed to Ericaceae taxa, or also Empetrum?). For types drawn in symbols without their names, only the "genus" names from FuKareK (1961) were used (e.g. Pinus and Alnus instead of Pinus silvestris and Alnus glutinosa). If in the original diagrams pollen type names were abbreviated, the name HEINRICHSWALDER DAMM (HWD)

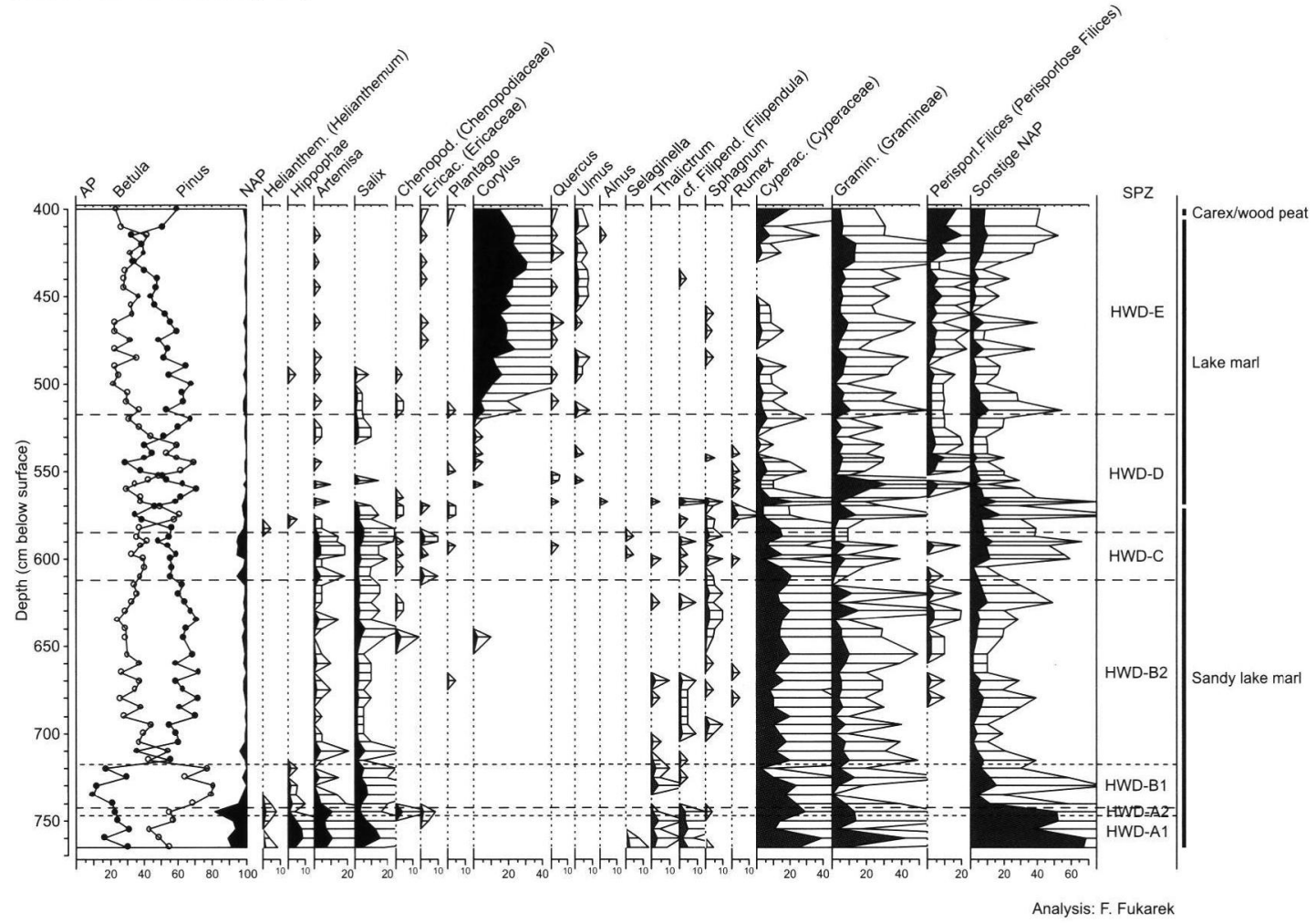

Fig. 4: Pollen percentage diagram „Heinrichswalder Damm“ (HWD). Black curves: pollen types included in the pollen sum; dotted curves: types excluded from the pollen sum. Pollen type nomenclature: original names (with supplemental names used in text for abbreviated pollen type names).

Abb. 4: Pollenprozentdiagramm „Heinrichswalder Damm“ (HWD). Schwarze Kurven: Pollentypen innerhalb der Pollensumme; punktierte Kurven: Typen außerhalb der Pollensumme. Pollentyp-Nomenklatur: originale Bezeichnungen (bei Abkürzungen wurden die vollständigen Namen dieser Typen in Klammern zugefügt). 
HÜTTENDAMM (HTT)

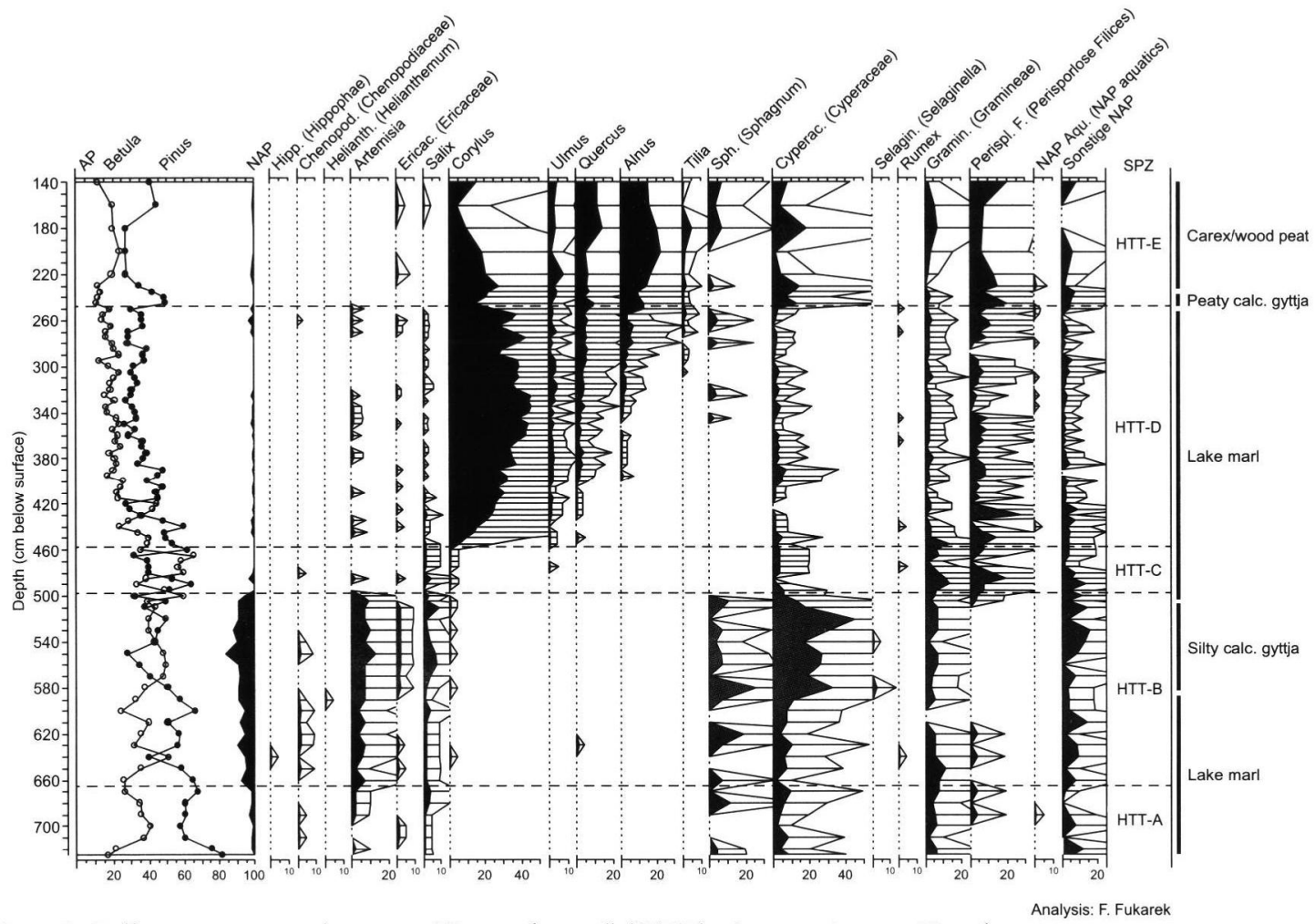

Fig. 5: Pollen percentage diagram „Hüttendamm“ (HTT). Annotation see Fig. 4.

Abb. 5: Pollenprozentdiagramm „Hüttendamm“ (HTT). Legende s. Abb. 4.

by which this type is referred to in the text is complemented between brackets.

Original percentage-values were imported in the TILIA 1.12 computer program (GRIMM 1992) and recalculated using a pollen sum with pollen types attributable to trees and shrubs (AP) and upland herbs (NAP). This NAP-concept differs from the 'sonstige NAP' of FuKAREK (1968) that includes also pollen produced possibly by wetland herbs. Relative pollen values of single samples at the base of cores HWD and GAL are presented in Table 1. Pollen diagrams (Figs. 4-7) were prepared with the TILIAGRAPH 1.18 and TGView 1.6.2 computer programs (Grimm 1992, 2004). Pollen types included in the sum are displayed as lines (Betula and Pinus) and with black curves, those excluded from the sum with grey curves; a 5-times exaggeration is displayed as open curves with depth bars. The pollen curves are ordered stratigraphically in order to facilitate a successional interpretation. The pollen diagrams are divided into 'Site Pollen Zones' (SPZ's) (cf. De Klerk 2002), which are a combination of informal acme zones and informal interval zones sensu Hedberg (1976). The description of the pollen zones and their correlation, carried out by comparing common trends in the pollen curves, is presented in Table 2.

The pollen zones covering the Weichselian Lateglacial and Early Holocene are interpreted in terms of 'Vegetation phases of Vorpommern' that were introduced by De KLeRK (2002) in order to avoid a widespread scientific confusion on the stratigraphical/geochronological 


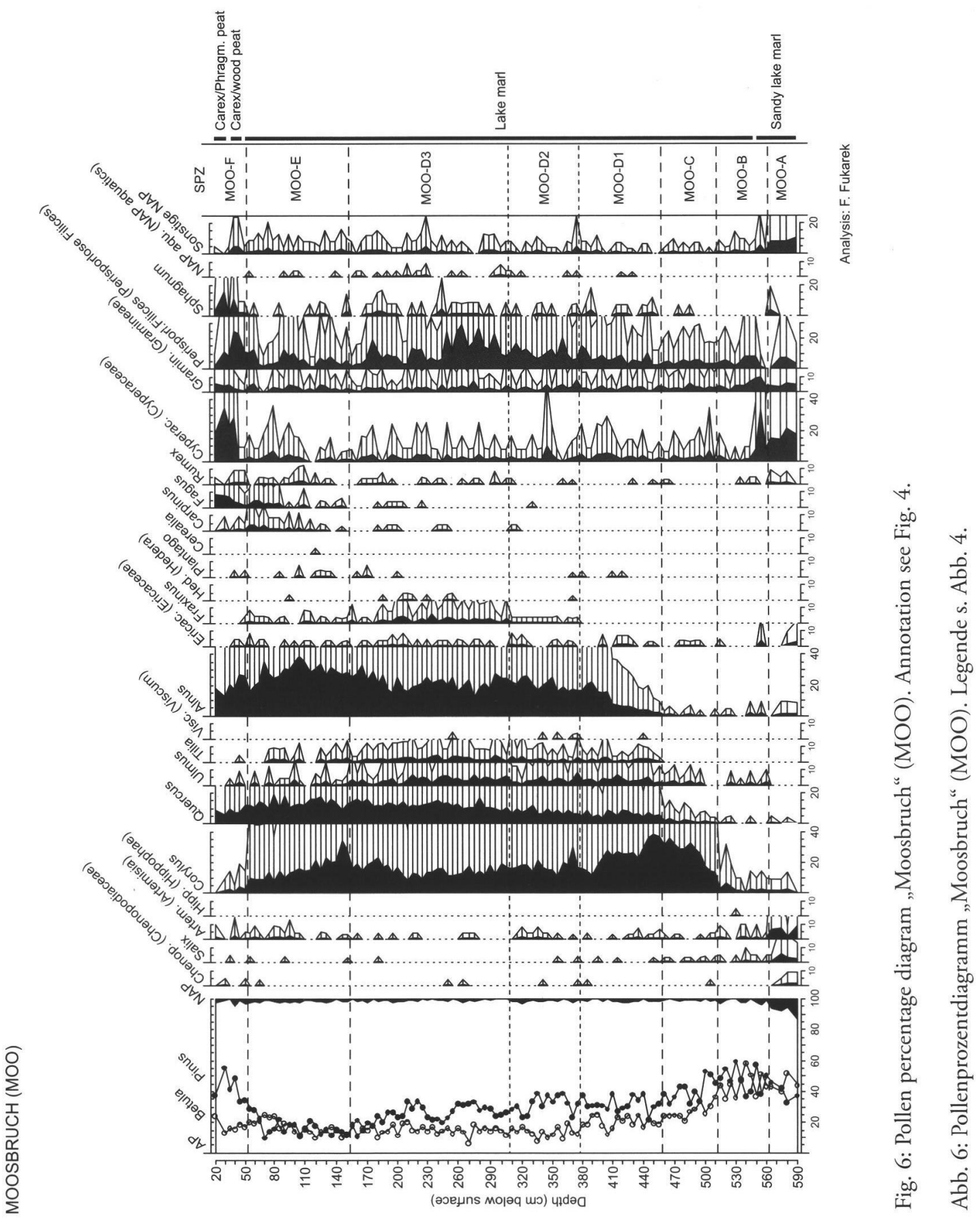




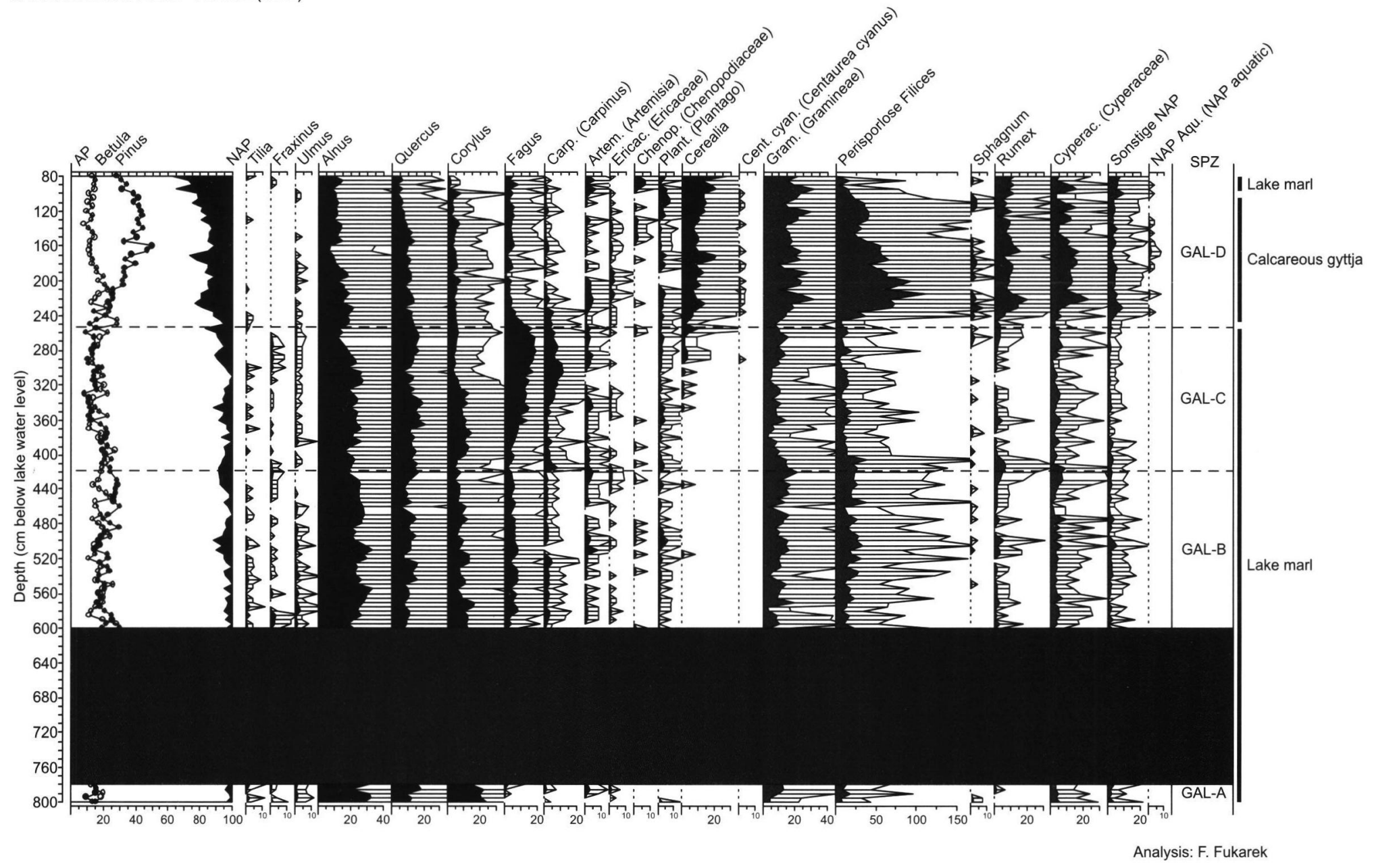

Fig. 7: Pollen percentage diagram „Galenbecker See - Rinne“ (GAL). Annotation see Fig. 4.

Abb. 7: Pollen-prozentdiagramm „Galenbecker See - Rinne“ (GAL). Legende s. Abb. 4. 
Tab. 1: Pollen percentage values of single samples at the basis of cores „Heinrichswalder Damm“ (HWD) and „Galenbecker See - Rinne“ (GAL).

Tab. 1: Pollenprozentwerte von Einzelproben an der Basis der Kerne „Heinrichswalder Damm“ (HWD) und „Galenbecker See - Rinne“ (GAL).

\begin{tabular}{|c|c|c|c|c|c|c|c|c|c|c|c|c|c|c|c|c|c|c|}
\hline Sample & $\frac{\mathscr{N}}{\underline{\underline{L}}}$ & 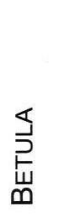 & ڤ્ & $\underset{⿱ 乛}{\stackrel{\infty}{z}}$ & 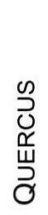 & $\stackrel{\leftrightarrows}{\risingdotseq}$ & 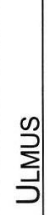 & $\begin{array}{l}\mathscr{N} \\
\stackrel{2}{2} \\
\frac{x}{\alpha} \\
\frac{\alpha}{4}\end{array}$ & 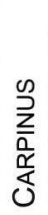 & 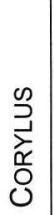 & 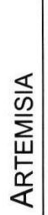 & 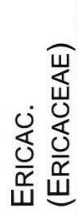 & 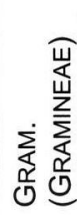 & 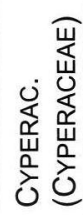 & 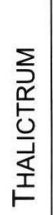 & 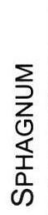 & 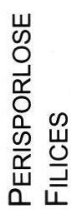 & 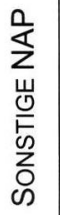 \\
\hline & 41.5 & 53.5 & 4 & - & 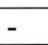 & - & 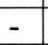 & - & - & - & 1 & - & 5 & 4 & 1 & - & & 7 \\
\hline GAL-900 & 17 & 6.0 & - & 29.5 & 14 & 4.5 & 3 & 2.5 & 1 & 20 & 1 & 1.5 & 4 & & & & & 1.5 \\
\hline
\end{tabular}

Tab. 2: Correlation and description of the site pollen zones (SPZ's) of pollen diagrams „Heinrichswalder Damm“ (HWD), „Hüttendamm“ (HTT), „Moosbruch“ (MOO) and „Galenbecker See - Rinne“ (GAL).

Tab. 2: Korrelation und Beschreibung der ,Site Pollen Zones’ (SPZ`s) der Pollendiagramme „Heinrichswalder Damm“ (HWD), „Hüttendamm“ (HTT), „Moosbruch“ (MOO) und „Galenbecker See - Rinne“ (GAL).

\begin{tabular}{|c|c|c|c|c|}
\hline \multicolumn{4}{|l|}{ SPZ's } & \multirow{2}{*}{$\begin{array}{l}\text { DESCRIPTION } \\
\text { Decreased values of Fagus pollen; values of } \\
\text { Cerealia and Pinus rise within this zone }\end{array}$} \\
\hline & & & GAL-D & \\
\hline & & MOO-F & GAL-C & High values of Carpinus and Fagus \\
\hline & & \multirow[t]{2}{*}{ MOO-E } & GAL-B & \multirow{2}{*}{$\begin{array}{l}\text { Decreased values of Ulmus; Carpinus and Fagus } \\
\text { present with low, continuous values }\end{array}$} \\
\hline & & & GAL-A & \\
\hline & & MOO-D3 & & \multirow{3}{*}{$\begin{array}{l}\text { Decreased values of Corylus and high, more or } \\
\text { less stable values of Ulmus, Quercus, Tilia and } \\
\text { Alnus; the sub-zones of MOO-D are based on } \\
\text { rises in the curve of Fraxinus }\end{array}$} \\
\hline & & MOO-D2 & & \\
\hline & HTT-E & MOO-D1 & & \\
\hline HWD-E & HTT-D & $\mathrm{MOO}-\mathrm{C}$ & & $\begin{array}{l}\text { High values of Corylus; values of UImus, Quercus, } \\
\text { Tilia and Alnus gradually rise }\end{array}$ \\
\hline HWD-D & HTT-C & MOO-B & & $\begin{array}{l}\text { Low values of NAP-types; high, fluctuating values } \\
\text { of Betula and Pinus }\end{array}$ \\
\hline HWD-C & HTT-B & MOO-A & & $\begin{array}{l}\text { High values of NAP-types; variable and fluctuating } \\
\text { values of Betula and Pinus }\end{array}$ \\
\hline HWD-B2 & HTT-A & & & Low NAP values; high values of Pinus \\
\hline HWD-B1 & & & & Low NAP values; high values of Betula \\
\hline HWD-A2 & & & & Peak of NAP-types \\
\hline HWD-A1 & & & & High values of NAP and Hippophae \\
\hline
\end{tabular}


Tab. 3: Used register maps and their signature in the „Landesarchiv Greifswald“ (cf. Fig. 8).

Tab. 3: Benutzte schwedische Matrikelkarten sowie deren Signatur im Landesarchiv Greifswald (vgl. Abb. 8).

\begin{tabular}{|l|l|l|}
\hline NR. & SIGNATURE & NAME \\
\hline 1 & Rep. 6a C IIla 14 & Wittstock \\
\hline 2 & Rep. 6a C IIla 23 & Demnitz och Altwikshagen \\
\hline 3 & Rep. 6a C IIla 13 & Lübz \\
\hline 4 & Rep. 6a C IVb 43 & Sarow och Jokemühl Torgelows Amts Heiderideriet \\
\hline 5 & Rep. 6a C IVb 40 & Torgelows Ampts Hollenderi \\
\hline 6 & Rep. 6a A IIla 37 & Torgelow - Fragment with Mückenborg \\
\hline 7 & Rep. 6a C IVb 38 & Grosse och Lütte Hammar \\
\hline 8 & Rep. 6a C IVb 41 & Ett Stijck af Torgelows Ampts Skog \\
\hline 9 & Rep. 6a C IVb 42 & Ett Stijck af Torgelows Ampts Skog \\
\hline 10 & Rep. 6a C IVb 44 & Rothemühl och Nuenska Heiderideriet. \\
\hline
\end{tabular}

subdivision of the Lateglacial (cf. Usinger 1985, 1998; Litt \& Stebich, i 999; Eriksen, 2002; De Klerk, 2004b). For readers not familiar with this terminology, additionally the more traditional terminology is provided. For a complete overview of the correlation of the vegetation phases of Vorpommern with traditional schemes reference is made to the correlation table of De KLERK (2002, 297; 2004a, 32).

The map of the landscape surrounding the Friedländer Große Wiese area around A.D. 1700 (Fig. 8) was based on several sheets of the Swedish register map (cf. Fig. 8 and Table 3) which were scanned, electronically fitted together, and subsequently redrawn according to the information presented on the maps supplemented with the information presented in the descriptive texts. Only „Urkarten“ (draft maps) were used that contain the information prior to editing and therefore can be considered more complete than the "Reinkarten“ (final maps). From the area of Müggenborg no draft map has been preserved, due to which this (small) area was drawn after the final map (cf. Table 3). The original textual descriptions can be found in the relevant sections in volumes 5 and 6 of the „Matrikelbänder" registered under Rep. 6a in the „Landesarchiv Greifswald“.

\section{Interpretation and discussion}

\subsection{The Lateglacial and Early Holocene}

The earliest vegetation phase recorded (HWDA1) is the Hippophaë phase sensu De KLerk (2002), that corresponds with the Dutch Bølling or the later part of the northwest-German Meiendorf. Large, dense stands of Hippophaë rhamnoides were present on the upland together with a mainly open vegetation consisting of a.o. Artemisia and Helianthemum. The pollen values indicate that also Salix must have been an important member of the vegetation in the region of the Friedländer Große Wiese. This phase is interpreted by De KLERK (2002) and De KLerk et al. (2001) to correspond with a relative warm phase that can be inferred from different proxies from European sites and that started around $12600 / 12500 / 12450{ }^{14} \mathrm{C}$ years B.P. (e.g. Lotter et al. I992; Ammann et al. i 994; Hammarlund \& Lemdahl i994; HoeK et al. 1999). The fact that Hippophaë could form large dense stands is due to the absence of competitive shadowcasting taxa: though birch trees were already present in Vorpommern at the onset of the Lateglacial (as demonstrated by DE KLERK et al. 2001), these were probably present 


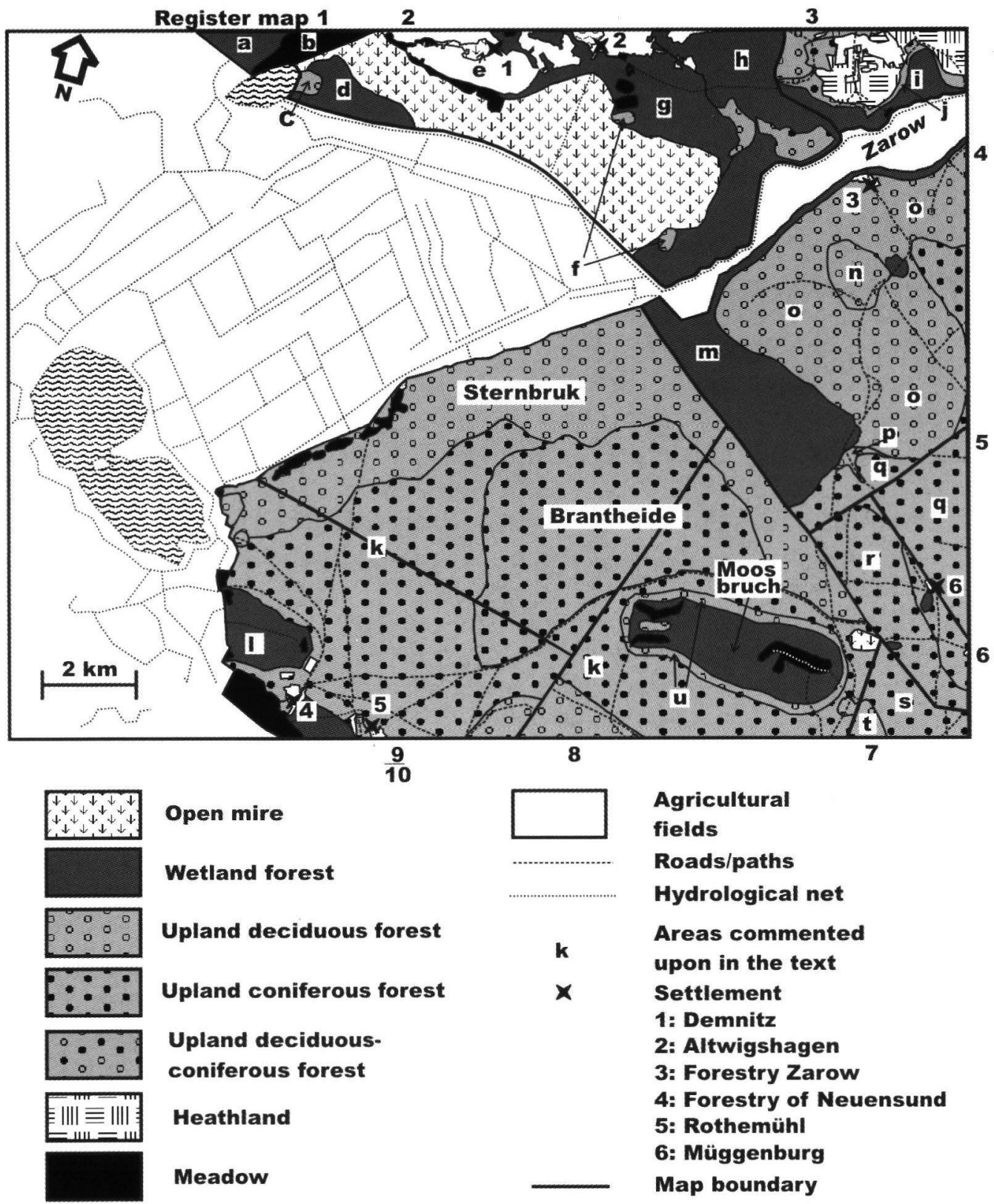

Fig. 8: The landscape surrounding the „Friedländer Große Wiese“ around A.D. 1700, based on several Swedish register maps.

Abb. 8: Die Landschaft um die „Friedländer Große Wiese“ um ca. A.D. 1700, neu gezeichnet nach verschiedenen schwedischen Matrikelkarten. 
only incidentally and were unable to expand extensively due to a dry contintental climate (cf. Usinger 1998) or due to insufficient soil development (cf. VAN GeEL 1996).

Only one sample (HWD-A2) contains a large peak of Artemisia and Chenopodiaceae pollen together with decreased values of Hippophae pollen. This sample represents Open vegetation phase II (the Older Dryas). It is assumed to have been a short, probably cooler phase in which Hippophaë rbamnoides mainly disappeared and upland herbs expanded. This phase started around $12000{ }^{14} \mathrm{C}$ years B.P. and lasted around 100 years (cf. De KLERK et al. 2001; De KLERK 2002). It is a conspicuous feature that this phase is registered prominently in pollen diagrams from northern Vorpommern with thick sediments (due to enlarged soil erosion), whereas it is absent or only minory indicated in pollen diagrams from $S$ Mecklenburg, $N$ Brandenburg, and the Berlin area (cf. inventory of De KLerK 2002, submitted). This is ascribed to a denser vegetation - possibly due to higher temperatures - in the southern areas (cf. DE Klerk \& Stolze 2002, De Klerk submitted) due to which increased soil erosion did not occur and this short phase is subsequently hardly recorded. The fact that Open vegetation phase II is displayed in the diagram HWD, however with thin sediments only (in accordance with its short duration), might be an indication that the Friedländer Große Wiese area was part of a transitional reach between the areas in the north and the areas in the south.

The closing of the upland vegetation is represented in SPZ HWD-B1 by the increase of Betula pollen, which marks the expansion of birch forests. In a later phase, also Pinus greatly expanded (SPZ's HWD-B2, HTT-A). This forested period is the Lateglacial Betulal Pinus forest phase sensu De KLERK (2002) (Alleröd; or: Bölling-Alleröd complex sensu Usinger (1985), or: sequence of „Bølling - Older Dryas - Allerød" sensu Litt \& Stebich (1999).
Expansion of forests during this phase might be related to a gradual shift to a more oceanic climate (cf. Usinger 1998; De KLerk et al. 2001), and/or to the development of more mature soils (cf. VAN GeEl 1996). The division of this phase into a subphase with high values of Betula pollen followed by a subphase with high values of Pinus pollen (as shown in the HWD diagram Fig. 4) indicate an affiliation of the Friedländer Große Wiese region with the regions of S Mecklenburg, N Brandenburg, and the Berlin area where pollen diagrams in general show a similar bipartition (cf. De KLERK 2002, submitted; De KLerk \& Stolze 2002); incidental deviations with a re-increase of Betula pollen towards the end of the forest phase (that also seems to show in the HTT diagram Fig. 5) are attributed to (extra)local expansion of birch carrs along the margins of the investigated basins (cf. Wolters 2002; Theuerkauf 2003).

After the forest phase, the upland vegetation opened-up again, and a new open vegetation with Artemisia and Ericales (probably also including Empetrum) developed (SPZ's HWD-C, HTT-B, MOO-A). This opening of the forests relates to the global cooling of the Open vegetation phase III (Younger Dryas) that started around $11000{ }^{14} \mathrm{C}$ years B.P. (cf. IsARIN, 1997). From the pollen values of Pinus it seems likely that pine trees remained important in the Friedländer Große Wiese area, but did not form closed stands. This vegetation phase is recorded in thick clastic sediments in study areas from northern Vorpommern displaying relative high NAP values (especially attributable to ericaceous taxa), whereas in the southern regions sediments are predominantly thin, organic, and show lower NAP values. These differences are again ascribed to a Lateglacial climate gradient due to which vegetation in the southern regions was denser and soil erosion was less severe than in the northern regions (cf. BRANDE 1995; De Klerk 2002, submitted; De Klerk \& STOLze 2002). An assumed intermediate area 
between N Vorpommern and S Mecklenburg, $\mathrm{N}$ Brandenburg, and the Berlin area consisting of extensive juniper stands (BRANDE 1995) is not supported by an inventory of the available data that shows a more or less random pattern of pollen diagrams with high values of Juniperus pollen (De KLERK submitted). Open vegetation phase III corresponds in the Friedländer Große Wiese pollen diagrams with organic sediments that are less prominently developed than the sediments of the preceding vegetation phase, which is similar to sites in S Mecklenburg, N Brandenburg, and the Berlin area. The relative high NAP values in the Friedländer Große Wiese pollen diagrams (including prominent values of Ericaceae pollen), however, are similar to the pollen diagrams of $\mathrm{N}$ Vorpommern. This indicates that for Open vegetation phase III the Friedländer Große Wiese area again might have belonged to a transitional area.

At the beginning of the Holocene temperatures rose again and the upland vegetation closed by expansion of Betula and Pinus forests (the Early Holocene Betula/Pinus forest phase; Preboreal).

FUKAREK (1968) interpreted the lower parts of the pollen diagrams HWD, HTT and MOO completely different. The single sample HWD-810 at the base of HWD (cf. Table 1) was interpreted to represent the Allerød, the subsequent open phase was correlated with the Younger Dryas, followed by the Preboreal. The next open phase (now correlated with the Open vegetation phase III/Younger Dryas) was interpreted by FuKareK (1968) to be an open phase during the Early Holocene that he named "Galenbecker Schwankung“. Though the single sample HWD-810 undoubtedly can be ascribed in the Lateglacial Betula/Pinus forest phase, as the high values of BETULA and low values of Artemisia indicate, the subsequent pollen sequences show that the higher SPZ's are older: the single sample, therefore, is probably a coring disturbance. Following the interpretation of diagram Heinrichswalder Damm, Fukarek (1968) also interpreted the Lateglacial/Early Holocene sections of the diagrams Hüttendamm and Moosbruch too young.

This unfortunate error influenced the dating of the developmental phases of the proglacial lake as reconstructed by BRAMER (1964, 1975, 1979), who posed several phases to last up to the „Bølling" (probably the chronostratigraphic Bølling-concept of MANGERUd et al., 1974), followed by a prominent development of soil frost features and a renewed glacial advance in the Older Dryas. A first formation of organic material assumed to date from the Alleröd is then followed by a gradual disappearance of the proglacial lake that should have happened during the Younger Dryas. The first deposition of lake marl in residual lakes in the Moosbruch, Galenbecker See and other deep basins in the Friedländer Große Wiese was assumed to have taken place at the Younger Dryas/Preboreal transition. A phase of dune formation is subsequently assumed for the Preboreal/Boreal.

Since a residual lake with lake marl deposition was already present at the Heinrichswalder Damm site during the early Lateglacial, the development phases reconstructed by BrAMER $(1964,1975,1979)$ must have occurred much earlier and probably had already ended before the beginning of the Lateglacial. A gradual termination of the proglacial lake during the Younger Dryas seems improbable. Most likely the dune formation must be dated to this period instead of the early Holocene. Archaeological finds dated dunes in the eastern part of the Ueckermünder Heide to the Younger Dryas (KAISER et al., 2001), indicating that this new interpretation is correct. 


\subsection{Early Holocene Corylus phase and the Middle Holocene}

A rise of CORYLus pollen in SPZ's HWD-E, HTT-D and MOO-C marks the invasion of hazel, which greatly expanded and became an important vegetation element. Increases in the values of Corylus pollen were dated in $\mathrm{N}$ Brandenburg at ca. $9100{ }^{14} \mathrm{C}$ years B.P. (Jahns 2000), whereas for northern Vorpommern an age of ca. $9300{ }^{14} \mathrm{C}$ years B.P. can be estimated from the studies of ENDTMANn (2002) and KAFfKe \& Kaiser (2002). A date of $9335 \pm 42$ ${ }^{14} \mathrm{C}$ years B.P. for the southern Ueckermünder Heide (KAISER et al. 2001) corresponds well with the dates from northern Vorpommern, though for unconvincing reasons the authors rejected this date as being too young.

Gradual increases of Ulmus, Quercus, Tilia, and Alnus pollen in the diagrams indicate that the associated taxa gradually expanded in the Friedländer Große Wiese region. Finally they became the dominant forest elements and formed stable populations for several thousands of years, as can be concluded from the hardly fluctuating pollen curves in the Moosbruch diagram. After the mid-Holocene elm decline around $5000{ }^{14} \mathrm{C}$ years B.P. (BIRKS \& Birks 1980), which defines the boundary between SPZ's MOO-D3 and MOO-E, Fagus and Carpinus gradually expanded in the upland vegetation, as is shown by increasing values in Fagus and Carpinus pollen.

Early occurrence of Plantago pollen in the Moosbruch diagram (SPZ MOO-D1/D2), as well as substantial values of Artemisia pollen in the Early Holocene sections of the Hüttendamm and Moosbruch diagrams, might point to forest clearance in the study area by Mesolithic humans. Also in the Rothenklempenow pollen diagram of KAISER et al. (2001) a possible anthropogenic influence seems to be registered in the Mesolithic. In general, however, early Holocene anthropogenic influence will be hard- ly to detect with the rather low pollen sums that can be expected for the pollen diagrams of the present paper (cf. section 3). Increased values of Artemisia and Plantago pollen above the elm decline in SPZ MOO-E point to increasing anthropogenical activities around the Moosbruch basin during the Neolithic.

The basis of the peat in core HWD is positioned below the decrease in Corylus pollen and the increase in Ulmus, Quercus, and Alnus pollen, i.e. at a substantially lower palynostratigraphic level than at the HTT-site where the basal peat contains higher values of Ulmus, Quercus, Alnus and Tilia pollen. The peat at the HWD-site might originate from organic material penetrating from a higher level (e.g. roots), but it is also possible that terrestrialisation at the HWD-site started considerably earlier than at the HTTsite. A ${ }^{14} \mathrm{C}$-date of $6800 \pm 100{ }^{14} \mathrm{C}$-years B.P. in the core HTT from the layer of peaty calcareous gyttja between 240 and $250 \mathrm{~cm}$ depth (FukareK 1968; cf. Bramer 1964) seems too young in comparison to dates around $7900 /$ $8300{ }^{14} \mathrm{C}$ years B.P. in $\mathrm{N}$ Brandenburg from core levels with similar upland pollen features (JAHns 2000, 2001). This younger age might be partly related to the presence of roots penetrating from a higher level: the vegetation which formed the covering Carex/wood peat probably rooted in the upper calcareous sediments.

Bramer (1964), as can be concluded from his argumentation, obviously assumed a synchronous beginning of peat formation in the Early Atlantic over the complete Friedländer Große Wiese and consequently concluded that also the Galenbecker See basin terrestrialised in this period and became reduced to the small deep channel. Actually, it cannot be accurately estimated when terrestrialisation of this basin started because no pollen analyses nor ${ }^{14} \mathrm{C}$-dates of its terrestrialised part are available. 


\subsection{The late Holocene}

The late Holocene is well recorded in the diagram GAL. Prominent is a maximum of FaGus and Carpinus pollen (GAL-C) that can be correlated with the Slavic period and the late Medieval (cf. Jahns \& Herking 2002). A closed curve of Cerealia pollen starts towards the top of SPZ GAL-C. The base of the closed curve of Secale pollen is dated in the eastern Ueckermünder Heide at A.D. 650 (Jahns \& Herking 2002).

The decline of Fagus pollen is dated in NE Germany and NW Poland around $600-800{ }^{14} \mathrm{C}$ years B.P. (Müller \& KoHL I966; Latalowa I 992; EndTMANn 2002). Above the decrease of FAGUS pollen in the GAL-diagram, high values of pollen attributable to cultivated plants and agricultural weeds (e.g. Artemisia, Plantago, Chenopodiaceae, Centaurea cyanus, Cerealia) occur. This shows a prominent deforestation of the landscape and the subsequent enlargement of agricultural area since the late Medieval. A similar pollen sequence is visible in a diagram from the eastern Ueckermünder Heide (JaHNS \& Herking 2002).

Fluctuations in the curves of the types mentioned previously might point to variations in the ratio between forest and fields in the course of time. A prominent decrease in values of Cerealia and Plantago pollen (indicating a reduction of fields) occurs at $170 \mathrm{~cm}$ depth. Assuming an age of ca A.D. 1200 for the zone boundary GAL-C and GAL-D and of ca 1950 for the top sediments of core GAL, it is possible to interpolate a date of ca A.D. 1450 for this reduced agriculture. It is unknown what might have caused this.

The rises of Cyperaceae pollen and Perisporlose Filices spores in zone GAL-D might indicate an increase of sedges and Thelypteris in the mire adjacent to the Galenbecker See. An increase of Cyperaceae pollen is possibly related to hay-making on the mires (cf. Segerström \& EMANueLs- son 2002). The high values of Gramineae and Rumex might indicate that also Pbragmites and wetland Rumex taxa expanded, though this pollen might also stem from upland taxa in the open landscape.

Peat formation in the Moosbruch at the cored location started clearly after the rise in FAGUS pollen and, thus, must be dated in the Slavic period/late Medieval. High values of Cyperaceae, Perisporlose Filices, and Sphagnum pollen and spores indicate a local peatforming vegetation of sedges, ferns, and mosses.

\subsection{Development of the Galenbecker See}

The sediments in the deep channel from which core GAL was derived are of relative young age: even the single sample at $900 \mathrm{~cm}$ depth (Table 1) seems to date from after the elm decline. The mineral subsoil in this channel is estimated around maximum $1 \mathrm{~m}$ below sea level (Bramer 1964), i.e. $2 \mathrm{~m}$ deeper than this basal sample. In most cases during coring, however, the mineral subsoil was not reached. Therefore, the basin basis may lay even deeper at the investigated location than the estimated depth.

Bramer (1964) had an explanation for the young age of the sediments in the channel. $\mathrm{He}$ states that sediment levels within the lake basin lay at a much lower level than the assumed synchronous levels in the surrounding mire. From his argumentation it becomes clear that he expected lake sediments to be deposited at the same elevation as synchronous peat layers in the surrounding mire. In order to explain the lake sediments to lie at a lower elevation, Bramer (1964) poses the hypothesis that the thawing of buried dead-ice in the basin of the Galenbecker See took place at an extra-ordinary late time during the Subboreal. Since, however, no datings are available from the peat layers within the Galenbecker See, neither palynological nor radiometric, the assumed synchronicity is only 
hypothetical. Since it is furthermore very likely that lake sediments in deep basins are deposited at a deeper elevation than contemporaneous peat layers in an adjacent mire, it is not necessary to explain the observed phenomena with an extremely late dead-ice thawing.

The zone boundary GAL-C/GAL-D, i.e. where FAGUS pollen decreases, corresponds with the transition from lake marl to calcareous gyttja. Since lake marl outside the channel-like depression in the Galenbecker See occurs only below the thick peat layers, and calcareous gyttja only above, this transition probably marks the start of the expansion of the lake. This shows that in the late Medieval the small lake, which was until then constricted to the deep channel, started to expand at the expense of the surrounding mire. This observation is in sharp contrast with Bramer (1964), who places the FAGUS/CARPINUS maximum between $500 \mathrm{BC}$ and $\mathrm{AD} 600$, and with the hypothesis of SuCCOw \& JeschKe (1990) that the size and shape of the lake had not substantially changed during the last 2000 years. Water level rises during the late Medieval, possibly due to anthropogenic activities (e.g. forest clearances and stowage for water mills), but possibly also related to climatic changes, have regularly been reported for NE Germany (e.g. Driescher i986; Jeschke i990; Kaiser I996; BLEILE 2002). Stowage for mills occurred downstream in the Zarow river that drains the Friedländer Große Wiese (as the small settlement "Zarowmühl“, meaning Zarow mill, indicates). This might have influenced the lake level of the Galenbecker See, possibly in combination with forest clearance and climate.

\subsection{The situation around A.D. 1700 as indicated in the Swedish register work}

Figure 8 presents the area surrounding the Friedländer Große Wiese around A.D. 1700. The Swedish register work is unfortunately not completely reliable in displaying areas that were of less importance for tax-levy (cf. AmELANG \& Gustavs 1998). This might explain the incorrect position of the Moosbruch and the gap between the maps south of the river Zarow (department Torgelow) and those north of the river Zarow (district Anklam). Though the southern border of the northern maps could be perfectly fitted to the present-day course of the river Zarow, this river was actually drawn as northern border on the southern maps. This indicates either a shift in the course of the river, or an inadequate mapping.

The area was sparsely populated: the many small villages that currently exist (cf. Fig. 1), thus, must have been erected after 1700A.D.

The register map covers only the northern fringe of the Friedländer Große Wiese and displays it as an open mire. The descriptive text mentions it as a marshy meadow of sedges with large areas of reed. Since a ditch crosses the area, and since it is mentioned in the descriptive volumes that due to the holding-back of water mowing is partly possible in dry years, reclamation of the Friedländer Große Wiese can be inferred to have started prior to the $18^{\text {th }}$ Century. Some small meadows were present along its northern shore around A.D. 1700. A forested area within the peatland (d) is mentioned as marshy with birches, alder and other not specified deciduous trees, whereas the small adjacent area (c) consisted of solid ground with alder and birch. The large meadow (b) is described as flat and marshy; the adjacent carr (a) was a former meadow on which small (= young?) birches and other scrubs grew.

Within the agricultural fields of Demnitz a small peatland (e) is described as flat and unforested. In the northeast, the open mire of the Friedländer Große Wiese grades into a large carr that is diversely described in the descriptive volumes. The area (g) is mentioned to have had a vegetation of small oaks, birches, willows, and similar (not specified) scrubs; the small areas (f) 
are mentioned to have been higher spots with oak and hazel. The area (h) is described as relatively wet containing large strong birches and alders, also containing some higher spots with oak and hazel (not individually drawn on the map), whereas the adjacent area (i) consisted of a dense alder carr. The fringe of mixed deciduous-coniferous forest adjacent to the carr (j) contained juniper, oak, beech, poplar, birch, and pine. Adjacent to this forest fringe was a heathland that partly consisted of deserted agricultural fields.

The deciduous forest south of the Friedländer Große Wiese, the Sternbruk, is mentioned to have consisted of oak, beech, hazel, and alder. The presence of alder indicates that some moist areas were present within the area, to which the name 'bruk' (= carr) also points. An additional remark was made that the area was relatively flat and suitable for forest clearance to create space for meadows. The meadows that already were present within the Sternbruk were noted to have had a marshy soil and to have been partly grown with bushes.

The coniferous forest south of the Sternbruk (k) contained large trees that were suitable as construction wood or as masts, whereas it is mentioned that the forests grew on heathland. The Bahrenbruch (l) is mentioned to have been grown with small birches. The Brantheide (Brant $=$ fire) is indicated on the map as a coniferous forest, of which the descriptive text mentions that it had been completely destructed by fire a few years prior to the surveying.

The forest (m) is drawn as a wetland forest on the map. The text, however, describes it as a beech forest with few oaks, though it is explicitly mentioned that inbetween - especially towards the northern map boundary - areas of shrubs and reed occurred that during the wetter years were rather marshy. The continuation of this area area along the river Zarow is described as marshy land with oak and alder trees, and shrubs of birch and willow, whereas several spots were so densely vegetated with reed that they were hardly accessible (which might be a further reason for the uncertain mapped course of the river Zarow).

The forest (n) is described as dense beech forest where in previous times the town Schermysel was located; the remaining beech forest (o) contained more oak. The forest $(p)$ is described as oak forest with few small pine trees, whereas the adjacent area (q) consisted of sandy moulds with moderately large pine trees suitable for fuel. The remaining forest areas are described as containing large coniferous trees with both large and small oak trees ( $\mathrm{r}$ ), as containing large pine trees (s), and as marshy lands with oak, beech, hazel, and alder ( $t$ ).

The Moosbruch is described as grown with (unspecified) bushes and scrubs, whereas it was surrounded by a fringe of oaks (u). Within the peatland an isle containing a pine forest was present. The meadows within the Moosbruch are mentioned to have had a marshy soil. Prominent is the ditch that crosses the Moosbruch, indicating that an artificial drainage of this peatland was already in use around 1700 A.D. Terrestrialisation of the Moosbruch, therefore, had proceeded to such level that the area was easily accessible.

This forested landscape-scenery is in sharp contrasts with the high amounts of pollen attributable to cultivated plants and agricultural weeds in the pollen diagram from the Galenbecker See. Interpolating between 1200 A.D. (basis of SPZ GAL-D) and 1950 (top of core GAL) provides the estimation that 1700 A.D. is registered between 135 and $140 \mathrm{~cm}$ depth. The register map shows only small agricultural fields near the villages Demnitz, Altwikshagen and Rothemühl, and near the forestry houses of Neuensund and Zarow. The agricultural fields inferred from the pollen diagram, therefore, must have been located predominantly on the northwestern, western and southwestern side of the Galenbecker See. 


\section{Concluding remarks and suggestions for}

\section{future research}

Although the palaeoecological significance of the pollen diagrams presented in this study is limited due to the small number of pollen types, the small sample interval provides a detailed pollen sequence for the complete Holocene and almost the complete Weichselian Lateglacial of the southwestern Ueckermünder Heide and, therefore, these diagram can be used as palynological standard for the time being until better material becomes available.

Due to erroneous chronological interpretations in the original study of FUKAREK (1968), the genesis of the Friedländer Große Wiese, the Galenbecker See, and the total Ueckermünder Heide have been wrongly reconstructed by Bramer (1964, 1975, 1979). With the revised interpretation these errors could be corrected.

Some indications were found that the study area was temporarily located in a transitional reach within a Lateglacial vegetational/climatic gradient in NE Germany. Future research into this gradient will benefit from the Friedländer Große Wiese analyses presented in this paper for the selection of adequate study areas.

Prominent is the very good preservation of the late Holocene in the sediments from the Galenbecker See. High-resolution palynological analyses combined with reliable radiometric dates can provide a good insight in the landscape development of the most recent Millennia in relation to anthropogenic activities. A detailed pollen morphological differentiation is necessary in order to get insight in the anthropogenic influence in the landscape.

An important palaeoecological research theme can be the origin and development of the Galenbecker See. Deeper corings should be carried out to get more insight in the location and composition of the mineral subsoil of the basin, especially in the area of the channel-like depression. The limnic sediments incidentally observed below the sand should get more attention, both geomorphologically and palaeoecologically, in order to reconstruct the oldest developmental phases of the area. Palaeoecological studies of the peat layers within the present lake may give insight in the terrestrialisation processes, of which currently little is known.

\section{Acknowledgements}

The revision of the diagrams from the Friedländer Große Wiese region were carried out in close connection with the research projects $\mathrm{Bi}$ 560/1-3 „Chronostratigraphy of northeastern Germany“ and Bi 560/1-5 „Specification of the earliest vegetation development at the site Reinberg (time slice I) " financed by the Deutsche Forschungsgemeinschaft (DFG), and EMAU 13-(95, 96) 1997 „Pollen and Macrofossilanalyses" financed by the Federal State Mecklenburg-Vorpommern, connected with the priority program "Changes of the geo-biosphere during the last 15,000 years" of the DFG. A. Kaffke and M. Kraus helped with the revision of the original pollen diagrams. B. Lintzen and P. Wiese assisted in the preparation of some of the figures. H. Wartenberg is greatly acknowledged for providing a (German) translation of the old-Swedish texts of the register work. A. Spangenberg kindly corrected the German text passages. H. Joosten and two anonymous reviewers are acknowledged for valuable comments on the text.

\section{References}

Amelang, N. \& Gustavs, O. (1998): Die Schwedische Landesaufnahme von Hiddensee - Ein GIS-gestützter Ansatz zur Datenerschließung. - In: Asmus, I.; PoradA, H.T.; Schleinert, D.: Geographische und historische Beiträge zur Landeskunde 
Pommerns - Eginhard Wegner zum 80. Geburtstag: 181-188, Schwerin (Helms).

Ammann, B., Lotter, A.F., Eicher, U., Gaillard, M.-J., Wohlfarth, B., Haeberli, W., Lister, G., Maisch, M., Niessen, F. \& Schlüchter, C. (1994): The Würmian Lateglacial in lowland Switzerland. - J. Quat. Science, 9: 119-125, Chichester.

Asmus, I. (1996): Die geometrische Landesvermessung von SchwedischPommern 1692-1709. - Balt. Studien, NF. 82: 79-98; Marburg.

Birks, H.J.B. \& Birks, H.H. (1980): Quaternary palaeoecology. - 289 S.; London (Edward Arnold).

BLEILE, R. (2002): InterdisziplinäreForschungen zu Wasserstandsschwankungen der „Oberen Seen" (Mecklenburg) in spätslawischer Zeit (Ende 10.-12. Jh.). - Greifswalder Geogr. Arb., 26: 179-182; Greifswald.

Bramer, H. (1963): Zur Entstehung der Friedländer Großen Wiese und des Galenbecker Sees (Naturschutzgebiet) (Vorläufige Mitteilung). - Naturschutzarbeit in Mecklenburg, 6: 14-23; Berlin.

Bramer, H. (1964): Das Haffstausee-Gebiet: UntersuchungenzurEntwicklungsgeschichte im Spät- und Postglazial. - 1-167 + appendices; Greifswald (Habil.-Thesis).

Bramer, H. (1972): Besonderheiten bei der Ausbildung eines Stausees im Bereich der Marginalzonen der letzten Vereisung. - Wiss. Z. Ernst-Moritz-Arndt-Univ. Greifswald, 21, Math.-nat. R., 1: 63-65; Greifswald.

Bramer, H. (1975): Über ein Vorkommen von Allerödtorf in Sedimenten der Ueckermünder Heide. - Wiss. Z. ErnstMoritz-Arndt-Univ. Greifswald, 24, Math.nat. R. 3/4: 183-187; Greifswald.

Bramer, H. (1979): Beiträge zur Physischen Geographie des Kreises Ueckermünde, Bezirk Neubrandenburg. - 89 S., Ueckermünde (Pädagogisches Kreiskabinett Ueckermünde).
Brande, A. (1995): Younger Dryas vegetation gradient in northeast Germany. - Terra Nostra, 95/2: 35; Bonn.

De KlerK, P. (2002): Changing vegetation patterns in the Endinger Bruch area (Vorpommern, NE Germany) during the Weichselian Lateglacial and Early Holocene.- Rev. Palaeobot. Palynol., 119: 275-309; Amsterdam.

De Klerk, P. (2004a): Changes in vegetation and environment at the LateglacialHolocene transition in Vorpommern (NE Germany). - Internat. Archäologie IAASTK, 5: 27-42; Rahden.

De KLERK, P. (2004b): Confusing concepts in lateglacial stratigraphy and geochronology: origin, consequences, conclusions (with special emphasis on the type locality Bøllingsø). - Rev. Palaeobot. Palynol., 129: 265-298; Amsterdam.

De Klerk, P. (submitted): Spatial patterns in vegetation, sedimentation processes, and climate during the Weichselian Lateglacial in the area of NE Germany. - Quat. Science Rev.; Oxford.

De Klerk, P. \& Stolze, S. (2002): Unterschiede in Vegetation und Sedimentation zwischen N-Vorpommern und S-Mecklenburg: Ein spätglazialer Klimagradient? - Greifswalder Geogr. Arb., 26: 161-165; Greifswald.

De Klerk, P., Helbig, H., Helms, S., Janke, W., Krügel, K., KühN, P., Michaelis, D. \& Stolze, S. (2001): The Reinberg researches: palaeoecological and geomorphological studies of a kettle hole in Vorpommern (NE Germany), with special emphasis on a local vegetation during the Weichselian Pleniglacial/ Lateglacial transition. - Greifswalder Geogr. Arb., 23: 43-131; Greifswald.

Dietrich, O., Dannowski, R., Quast, J. \& Tauschke, R. (1996): Untersuchungen zum Wasserhaushalt nordostdeutscher Niedermoore am Beispiel der Friedländer Großen Wiese und des Oberen Rhinluchs.- 
ZALF-Berichte, 25: 1-59; Müncheberg.

Driescher, E. (1986): Historische Schwankungen der Wasserstandes von Seen im Tiefland der DDR. - Geogr. Ber., 31: 159171; Berlin.

EndtMann, E. (2002): Das „Herthamoor“ - ein palynostratigraphisches Leitprofil für das Holozän der Insel Rügen. - Greifswalder Geogr. Arb., 26: 143-147; Greifswald.

ERIKSEN, B.V. (2002): Reconsidering the geochronological framework of Lateglacial hunter-gatherer colonization of southern Scandinavia. - Jutland Arch. Soc. Publ., 39: 25-41; Højbjerg.

FukareK, F. (1961): Die Vegetation des Darß und ihre Geschichte. - Pflanzensoziologie, 12: 1-321; Jena.

Fukarek, F. (1968): Pollenanalytische Untersuchungen in Meckl. - 34 S.; Greifswald (Project report).

FukareK, F. (1972): Ein Beitrag zur Entwicklungsgeschichte des Kernbruchs bei Feldberg. - Naturschutzarbeit in Meckl., 15: 52-61; Berlin.

Grimm, E.C. (1992): TILIA 1.12 and TILIAGRAPH 1.18 (software). - Springfield, Illinois (Illinois State Museum).

Grimm, E.C. (2004): TGView 1.6.2 (software).- Springfield, Illinois (Illinois State Museum).

Hammarlund, D. \& Lemdahl, G. (1994): A Late Weichselian stable isotope stratigraphy compared with biostratigraphical data: a case study from southern Sweden. - J. Quat. Science, 9: 13-31; Chichester.

HedberG, H.D. (ed.) (1976): International stratigraphic guide: a guide to stratigraphic classification, terminology, and procedure.200 S.; New York (Wiley).

Heller, H. \& Schimanski, E. (1966): Wasserwirtschaft und Landschaftsgestaltung in der Friedländer Großen Wiese.Naturschutzarbeit in Mecklenburg, 9(3): 4-10; Berlin.
Hoek, W.Z., Bohncke, S.J.P., Ganssen, G.M. \& Meijer, T. (1999): Lateglacial environmental changes recorded in calcareous gyttja deposits at Gulickshof, southern Netherlands.Boreas, 28: 416-432; Oslo.

ISARIN, R.F.B. (1997): The climate in northwestern Europe during the Younger Dryas: A comparison of multi-proxy climate reconstructions with simulation experiments. - Nederl. Geogr. Studies, 229: 1-160; Utrecht.

Iversen, J. (1962): F. Fukarek: Die Vegetation des Darss und ihre Geschichte. - Bot. Tidsskrift, 58: 245-246; Kopenhagen.

Jahns, S. (2000): Late-glacial and Holocene woodland dynamics and land-use history of the Lower Oder valley, north-eastern Germany, based on two, AMS ${ }^{14} \mathrm{C}$-dated, pollen profiles. - Veget. Hist. Archaeobot., 9: 111-123; Berlin.

Jahns, S. (2001): On the Late Pleistocene and Holocene history of vegetation and human impact in the Ücker valley, north-eastern Germany. - Veget. Hist. Archaeobot., 10: 97-104; Berlin.

Jahns, S. \& Herking, C. (2002): Zur holozänen und spätpleistozänen Vegetationsgeschichte im westlichen Odergebiet. - In: Gringmuth-Dallmer, E. \& Leciejewicz, L. (Hrsg.): Forschungen zu Mensch und Umwelt im Odergebiet in ur- und frühgeschichtlicher Zeit. - Römisch-Germ. Forschungen, 60: 33-49; Mainz.

Jeschke, L. (1990): Der Einfluß der Klimaschwankungen und Rodungsphasen auf die Moorentwicklung im Mittelalter. - Gleditschia, 18: 115-123; Berlin.

Joosten, H. \& De Klerk, P. (2002): What's in a name? Some thoughts on pollen classification, identification, and nomenclature in Quaternary palynology. - Rev. Palaeobot. Palynol., 122: 29-45; Amsterdam.

Kaffke, A. \& Kaiser, K. (2002): Das Pollendiagramm „Prerower Torfmoor" auf dem 
Darß (Mecklenburg-Vorpommern): neue Ergebnisse zur holozänen Biostratigraphie und Landschaftsgeschichte. - Meyniana, 54: 89-112; Kiel.

KAISER, K. (1996): Zur hydrologischen Entwicklung mecklenburgischer Seen im jüngeren Quartär. - Peterm. Geogr. Mitt., 140: 323-342; Gotha.

Kaiser, K., Endtmann, E., Bogen, C., CzakóPAP, S. \& KÜHN, P. (2001): Geoarchäologie und Palynologie spätpaläolithischer und mesolithischer Fundplätze in der Ueckermünder Heide, Vorpommern. - Z geol. Wiss., 29: 233-244; Berlin.

Kaiser, K., Bogen, C., Czakó-Pap, S. \& Janke, W. (2003): Zur Geoarchäologie des mesolithisch-neolithischen Fundplatzes Rothenklempenow am Latzigsee in der Ueckermünder Heide (Vorpommern). - Greifswalder Geogr. Arb., 29: 27-68; Greifswald.

KLoss, K. (1966a): Die Pflanzengesellschaften des Grünlandes der Friedländer Großen Wiese (Ost-Mecklenburg). - Arch. Natursch. u. Landschaftsf., 6: 103-121; Berlin.

KLoss, K. (1966b): Die Moorniederungen OstMecklenburgs - eine Betrachtung unter dem Gesichtspunkt des Naturschutzes. - Naturschutzarbeit in Meckl. 9(2): 20-24; Berlin.

KLoss, K. (1970): Veränderungen in der Grünlandvegetation der Friedländer Großen Wiese von 1960 bis 1967.-Z. Landeskultur, 11: 133-144; Berlin.

Koppisch, D., Roth, S. \& Hartmann, M. (2001): Vom Saatgrasland zum wieder torfspeichernden Niedermoor - Die Experimentalanlage Am Fleetholz/Friedländer Große Wiese. - In: Succow, M. \& JoosTEN, H. (Hrsg.): Landschaftsökologische Moorkunde: 497-504; Stuttgart (Schweizerbart).

Latalowa, M. (1992): Man and vegetation in the pollen diagrams from Wolin island (NW Poland). - Acta Palaeobot., 32: 123-249; Krakow.
Litt, T. \& Stebich, M. (1999): Bio- and chronostratigraphy of the lateglacial in the Eifel region, Germany. - Quat. Intern., 61: 5-16; Oxford.

Lotter, A.F., Eicher, U., Siegenthaler, U. \& BirKs, H.J.B. (1992): Late-glacial climatic oscillations as recorded in Swiss lake sediments. - J. Quat. Science, 7: 187-205; Chichester.

Mangerud, J., Andersen, S.T., Berglund, B.E. \& Donner, J.J. (1974): Quaternary stratigraphy of Norden, a proposal for terminology and classification. - Boreas, 3 : 109-128; Oslo.

MüLleR, H.M. \& KoHL, G. (1966): Radiocarbondatierungen zur jüngeren Vege-tationsentwicklung Südostmecklenburgs. - Flora Abt. B., 156: 408-418; Jena.

Reincke, J. \& LöSER, R. (2000): Zur Geologie der Friedländer Großen Wiese und der Brohmer Berge - Bericht über die Herbstexkursion 1999 des Geowissenschaftlichen Vereins Neubrandenburg. - Neubrandenburger Geol. Beitr., 1: 46-59; Neubrandenburg.

Roth, S., Koppisch, D., Wichtmann, W. \& Zeitz, J. (2001): „Moorschonende Grünlandnutzung" - Erste Erfahrungen auf nordostdeutschen Niedermooren. - In: Succow, M.; Joosten, H. (Hrsg.): Landschaftsökologische Moorkunde: 472-480; Stuttgart (Schweizerbart).

Schmidt, W. \& Scholz, A. (1993): Das Niedermoor Friedländer Große Wiese, landschaftsökologische Zielstellung und angelaufene Maßnahmen zur Erhaltung und Renaturierung. - Naturschutz u. Landschaftspflege in Brandenburg, Sonderheft Niedermoore: 41-46; Potsdam.

Scholz, A., Pöplau, R. \& Warncke, D. (1995): Wiedervernässung von Niedermoor Ergebnisse eines Versuches in der Friedländer Großen Wiese, Brandenburg. - Telma, 25: 69-84; Hannover.

Schulz, W. (1965): Die Stauchendmoräne der 
Rosenthaler Staffel zwischen Jatznick und Brohm in Mecklenburg und ihre Beziehung zum Helpter Berg. - Geologie, 14: 564-588; Berlin.

Schulz, W. (1998): Streifzüge durch die Geologie des Landes Mecklenburg-Vorpommern.- 192 S.; Schwerin (cw Verlagsgruppe).

Segerström, U. \& EMANUelsson, M. (2002): Extensive forest grazing and hay-making on mires - vegetation changes in south-central Sweden due to land use since Medieval times. - Veget. Hist. Archaeobot., 11: 181190; Berlin.

Succow, M. (2001): Durchströmungsmoore.In: Succow, M.; Joosten, H. (Hrsg.): Landschaftsökologische Moorkunde: 365378; Stuttgart, (Schweizerbart).

Succow, M. \& Jeschke, L. (1990): Moore in der Landschaft: Entstehung, Haushalt, Lebewelt, Verbreitung, Nutzung und Erhaltung der Moore. - 2. Aufl.: 268 S.; Leipzig (Urania).

Theuerkauf, M. (2003): Die Vegetation NO-

Deutschlands vor und nach dem Ausbruch des Laacher See-Vulkans (12880 cal. BP).Greifswalder Geogr. Arb., 29: 143-189; Greifswald.
Usinger, H. (1985): Pollenstratigraphischer, vegetations- und klimageschichtliche Gliederung des „Bölling-Alleröd Komplexes" in Schleswig-Holstein und ihre Bedeutung für die Spätglazial-Stratigraphie in benachbarten Gebieten. - Flora, 177: 143; Jena.

Usinger, H. (1998): Pollenanalytische Datierung spätpaläolitischer Fundschichten bei Ahrenshöft, Kr. Nordfriesland. - Mitt. Arch. Ges. Schleswig-Holstein u. Arch. Landesamt. Schleswig-Holstein, 8: 50-73; Kiel.

VAN Geel, B. (1996): Factors influencing changing $\mathrm{AP} / \mathrm{NAP}$ ratios in NW-Europe during the Late-Glacial period. - Il Quaternario, 9: 599-604;

WARTENBERG, H. (1994): Die Schwedischen Landesvermessung von Vorpommern und Stettin 1692-1709. - Pommern, Kunst, Geschichte, Volkstum, 32(4): 5-12; Lübeck.

Wolters, S. (2002): Vegetationsgeschicht-liche Untersuchungen zur spätglazialen und holozänen Landschaftsentwicklung in der Döberitzer Heide (Brandenburg). - Dissertationes Botanicae, 366: 1-157; Berlin. 